\title{
Strategi Pemasaran Untuk Meningkatkan Volume Penjualan Pada Perusahaan Genting Ud. Berkah Jaya
}

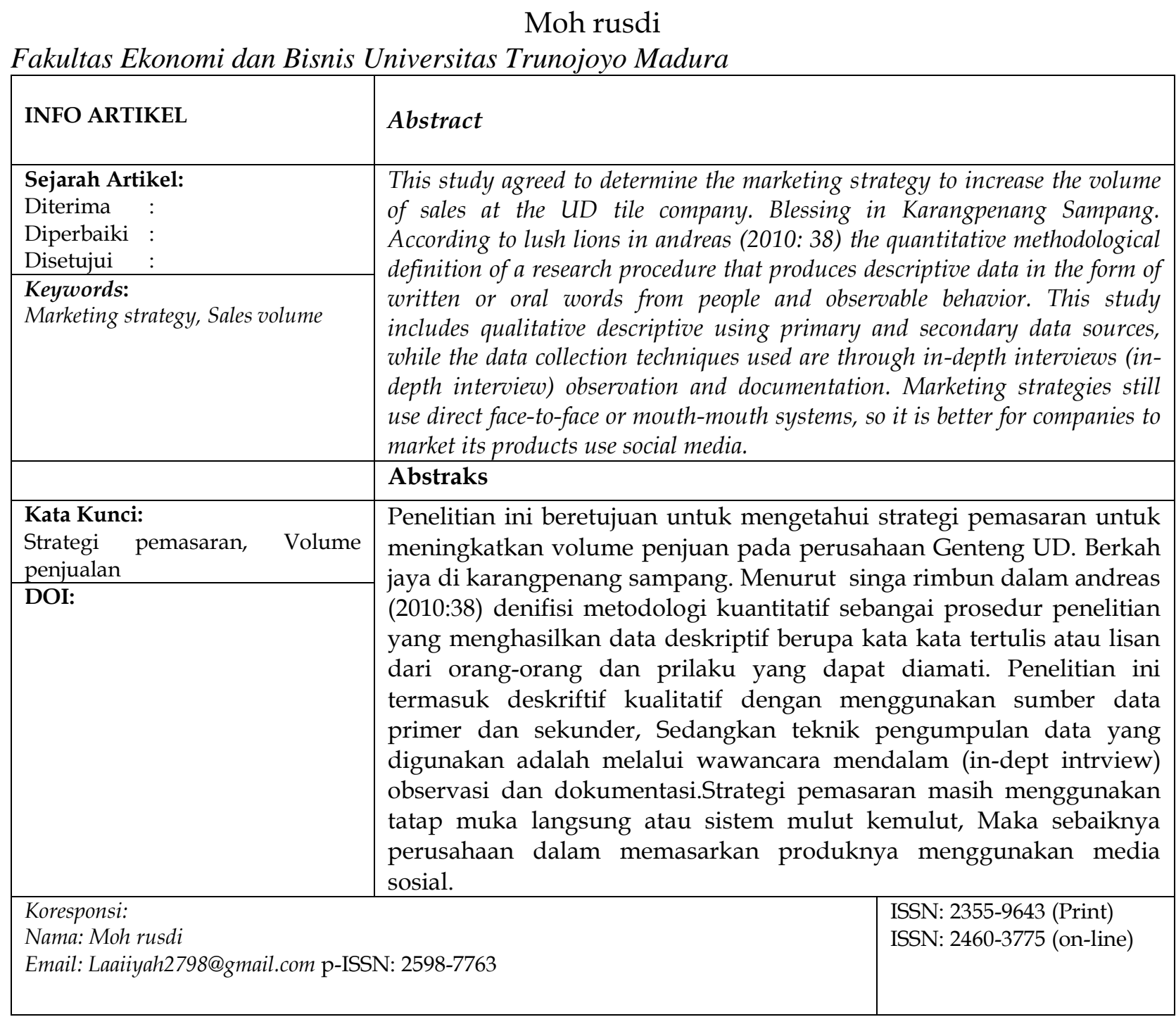

\section{PENDAHULUAN}

A. Latar Belakang Masalah

Pada dasarnya setiap perusahaan yang menghasilkan suatau barang atau jasa perlu kegiatan pemasaran, Karena pemasaran merupakan kegiatan pokok yang harus dilakukan Oleh setiap Perusahaan guna mencapai tujuan perusahaan itu sendiri. Setiap perusahaan yang menghasikan barang diharapkan selalu mengerti dan memahami apa yang terjadi di pasar dan apa yang menjadi keinginan konsumen, Di era globalisasi seperti saat ini, Munculnya persaingan dalam dunia bisnis tidak bisa dihindari lagi, adanya pesaing, Oleh karena itu Perusahaan dihadapkan dengan berbagai peluang dan ancaman, Baik yang berasal dari luar maupun dari dalam negeri,

Semakin sengitnya persaingan dapat dipicu oleh semakin majunya teknologi, salah satunya teknologi produksi, Kemajuan teknologi produksi 
berdampak pada sulitnya mempedakan antara produk - produk suatu perusahaan dengan perusahaan yang lainnya,

Untuk itu hal yang perlu diperhatikan yaitu kebijaksanaan produk, harga , promosi, dan distribusi. Dengan demikian sudah tentu pemasaran merupakan fungsi dari keberhasilan dan tercapainya tujuan yang diharapkan sehingga dapat memperoleh kelangsungan hidup perusahaan. (Tjiptono, 2000, 24).

Kegiatan pemasaran suatu perusahaan memiliki beberapa tujuan yang hendak dicapai, baik tujuan jangka pendek maupun tujuan jangka panjang. Dalam jangka pendek biasanya untuk merebut hati konsumen terutama untuk produk yang baru diluncurkan. Sedangkan dalam jangka panjang dilakukan untuk mempertahankan produk-produk yang sudah ada agar tetap eksis. Secara umum, Memahami konsep pemasaran, maka perlu diperkenalkan suatu pemahaman mengenai konsep strategi pemasaran. Untuk menghadapi di dalam mendapatkan pelanggan, suatu perusahaan harus menyadari bahwa tidaklah muda tanpa ada sebuah tindakan nyata berupa kerja keras dengan menggunakan strategi yan tepat untuk meningkatkan jumlah pelanggan, strategi merupakan kunci penting terhadap keberhasilan sebuah perusahaan dalam meraih pelanggan. Konsumen saat ini menghadapi beranika pilihan produk, merek, harga, serta pemasok, Untuk menentukan niat yang akan di ambil, maka konsumen akan mempertimbangkan penawaran mana yang akan memberikan mamfaat dan nilai tertinggi membangun dan menjalan bisnis agar menjadi sukses dan terpercaya tidak hanya terpaku pada beberapa baik produk atau jasa yang titawarkan. Faktor penting lsinnya yang turut mempengaruhi kepuasan konsumen akan produk atau jasa dari bisni adalah adanya pelayanan yang baik. Today competition essentially takes place at the produk augmentation level" ( Kotler,2003,408).

Perusahaan merupakan suatu bentuk usaha eceran yang mempunyai operasi relative besar, margin yang rendah, volume yang tinggi dan bersifat pasar yang dirancang untuk memenuhi kebutuhan konsumen. Dengan keuntungan yang kecil maka diharapkan perusahaan mampu mencapai volume jual yang tinggi agar keuntungan yang diperoleh dapat maksimal.

Genteng merupakan atap tutup rumah yang terbuat dari tanah liat yang di cetak lalu dibakar. Di Indonesia daerah penghasil genteng ada disetiap propinsi, propensi jawa tengah, nama genteng sokka, propensi jawa barat, nama genteng jati wangi, dan propensi jawa timur nama genteng karang penang,

Di karang penang sendiri terdapat sebanyak 175 unit perusahaan yang bergerak di bidang perusahaan genteng yang sudah beroperasi kurang lebih selama 30 tahun dan tetap menggunakan cara tradisional untuk mengelola produksinya. Genteng karang penang mempunya ciri khas sendiri,umunya tanah didaerah tersebut merupakan tanah istimewa dan tanah liat yang berkualitas bagus, bila dimanfaatkan sebagai bahan baku membuatan genteng menghasil prodak yang tidak mudah pecah bahkan kokoh dan bisa tahan dalam jangka yang sangat lama.

Berjarak sekitar $25 \mathrm{~km}$ dari kota sampang, kecamatan karang panang yang terletak diarea dataran tinggi berbukit berada di bagia utara kabupaten sampang dan berbatasan dengan kabupaten Pamekasan, memasuki wilayah tersebut, seketika pemandangan berubah mira bata. Hampir disetiap sudut desa dipenuhi dengan jajaran genteng, baik yang sudah siap dipasarkan atau yang masih dalam tahap proses produksi dan pematangan. Khususnya desa tlambah yang berada di kecamatan karang penang kabupaten sampang, merupakan desa produsen genteng terbesar yang ada di madura. Berdasarkan informasi dari Bapak samito selaku pemilik perusahaan Genteng UD. Berkah jaya sentosa bahwa wilayah pemasaran genteng karang penang meliputi bebarapa kota khususnya di kota Madura meliputi, Pamekasan, sumenep, sampang dan bangkalan, khusus di luar pulau Madura, kota Banyuwangi, probolinggo, jember Surabaya, solo. Dengan tingkat bervariasi tergantung model genteng yang di produksi.

Luasnya wilayah, pemasaran nampaknya tidak diikuti dengan peningkatan. Tingkat penjualan selama tiga tahun terakhir mengalami penurunan. Sebagai gambaran dapat ditunjukan data volume penjualan perusahaan genteng UD. Berkah jaya sentosa di Kecamatan Karangpenang yakni pada table berikut.

Volume Penjualan Genteng Periode Tahub 20162018

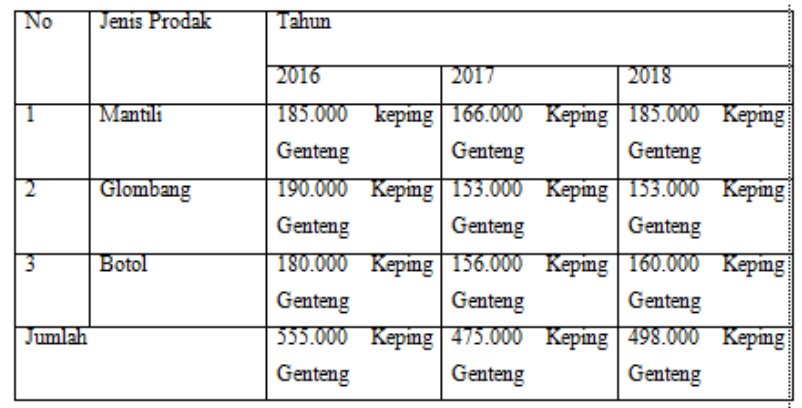

Pada tabel di atas menunjukan adanya 
penurunan tingkat penjualan selama tiga tahun terakhir. Tahun 2016 tingkat penjualan mencapai 555.000 genteng, Selanjutnya pada tahun 2017 tingkat penjualan mencapai 475.000 genteng, terjadi penurunan penjualan dan pada tahun 2018 penjualan naik mencapai 498.000 genteng, atau mulai meningkat Kondisi ini di alami oleh perusahaan UD. Berkah jaya sentosa di Karang pengang Kabupaten Sampang yang tergolong cukup besar. Sehingga mengindikasikan bahwa secara umum terjadi Penurunan volume penjualan ini merupakan permasalahan yang perlu segara ditangani.

Berdasarkan survey dan wawancara dengan bapak Samito selaku pemilik perusahaan UD. Berkah jaya sentosa di Desa Tlambah Kecamatan Karang penang Kabupaten Sampang. Diperoleh informasi bahwa faktor yang saat ini mempengaruhi volume penjualan tidak berkembang dan melemah. Faktor utama adalah kurangnya strategi yang diterapakan oleh perusahaan dan tingkat persaingan yang semakin sengit di perusahaan genteng, teknologi yang digunakan masih tradisional. Dan strategi promosi masih melemah. Tingkat persaingan yang semakin ketat di dalam perusahaan genteng, terjadi akibat tumbuhnya perusahaan-perusahaan baru yang juga turut bersaing dalam industry genteng.

\subsection{Rumusan Masalah}

1. Bagaimana faktor-faktor yang mempengaruhi volume penjualan di Perusahaan Genteng UD. Berkah jaya?

2. Bagaimana bauran pemasaran di Perusahaan Genteng UD. Berkah jaya?

3. Bagaimana strategi pemasaran di Perusahaan Genteng UD. Berkah jaya?

\subsection{Tujuan Penelitian}

1. Untuk mengetahui Bagaimana faktorfaktor yang mempengaruhi volume penjualan di perusahaan Genteng UD, Berkah jaya?

2. Untuk mengetahui Bagaimana bauran pemasaran di perusahaan Genteng UD, Berkah jaya?

3. Untuk mengetahui bagaimana strategi pemasaran di perusahaan Genteng UD, Berkah jaya?

1.4 Manfaat Penelitian

Dari hasil penelitian ini penulis dapat memberikan manfaat bagi:

\section{Bagi penulis}

Sebagai media membelajaran dalam mengembangkan wawasan dalam dunia bisnis. Serta dapat memberikan pengalaman untuk terjun langsung di dalam perusahaan.

\section{Bagi pembaca}

Mampuh memberikan sumbangan pemikiran untuk selanjutnya diharapkan dapat digunakan sebagi bahan masukan dan perbandingan dalam mengadakan penelitian selanjutnya yang tertarik untuk meneliti masalah kurangnya strategi pemasaran bagi perusahaan.

\section{Bagi perusahaan}

Adanya penelitian ini supaya memberikan ide - ide yang positif dan memberikan masukan masukan yang bagus bagi perusahaan guna sebagai bahan pijakan bagi perusahaannya.

\section{Landasan Teori}

1. Pengertian Pemasaran

Pemasaran adalah sebuah proses kemasyarakatan dimana individu dan kelompok memperoleh apa yang mereka butuhkan dan inginkan dengan menciptakan, Menawarnak dan secara bebas mempertukarkan produk dan jasa yang bernilai dengan orang lain (Kotler , 2009:5).

Sedangkan menurut stanton yang di kutip oleh Swastha dan Irawan (2003:5) Pemasaran adalah suatu sistem keseluruhan dari kegiatankegiatan bisnis yang ditunjukan untuk merencanakan, menentukan harga, mempromosikan, dan mendistribusikan barang dan jasa yang memuaskan kebutuhan berdasarkan kepada pembeli yang ada maupun pembeli poternsial.

Berdasarkan definisi di atas, dapat dijelaskan bahwa pemasaran di arahkan kepada usaha pemuasan kebutuhan dan keinginan konsumen untuk memperoleh keuntungan yang diharapkan melalui proses pertukaran atau transaksi.

2. Strategi Pemasaran

Strategi adalah keseluruhan konsep bagaimana sebuah perusahaan mengatur dirinya sendiri dan semua kegiatan dengan tujuan agar bisnis yang dijalankan berhasil, melakukan persaingan, dan melakukan imbal hasil kepada pemegang saham (Charles, 2010:9). Sedangkan menurut Assauri (2013:15) strategi pemasaran yaitu serangkaian tujuan dan sasaran, kebijakan dan aturan yang memberi arah kepada usaha-usaha pemasaran perusahaan dari waktu ke waktu, pada masingmasing tingkatan, acuan serta alokasinya, terutama sebagai tanggapan perusahaan dalam menghadapi lingkungan dan keadaan persaingan yang selalu berubah. Sedangkan strategi pemasaran menurut Swasta (2008:5) adalah suatu system keseluruhan dari kegiatan usaha melalui perencanaan, penentuan harga, mempromosikan, dan mendistribusikan barang dan jasa yang 
memuaskan dan memenuhi kebutuhan pembeli. Dari pendapat di atas dapat disimpulkan bahwa strategi pemasaran memberikan arah dalam kaitannya dengan segmentasi pasar, identifikasi pasar sasaran, positioning dan bauran pemasaran. Bauran pemasaran (marketing mix) terdiri dari empat elemen yaitu produk, harga, promosi, tempat. Sementara itu menurut Hurriyati (2010:62), untuk pemasaran jasa perlu bauran pemasaran yang diperluas dengan penambahan tiga unsur, yaitu orang, fasilitas dan proses sehingga menjadi 7P. Ketujuh elemen tersebut saling berhubungan satu sama lainnyadan dapat dikombinasikan sesuai dengan lingkungan, baik di dalam maupun di luar perusahaan agar tujuan perusahaan tercapai Kotler (2009:6).

\section{METODOLOGI}

Jenis Data

Jenis penilitian ini menggunakan metode deskriptif kualitatif. Menurut singa rimbun dalam andreas (2010:38) denifisi metodologi kuantitatif sebangai prosedur penelitian yang menghasilkan data deskriptif berupa kata kata tertulis atau lisan dari orang-orang dan prilaku yang dapat diamati. Untuk pengumpulan data dan informasi yang diberikan dalam penulisan ini, penulis memperoleh data yang berasal dari dokumen maupun keterangan lisan dari pemilik perusahaan dan karyawan perusahaan Genting UD. Berkah jaya.

Waktu dan tempat penelitian

Penelitian ini berlokasi di perusahaan Genting UD.Berkah jaya di Jalan Raya Tlambah Karangpenang Sampang. Penelitian ini dilakukan dengan mengikuti seluruh kegiatan yang ada di perusahaan.

Sumber Data

Sumber data yang digunakan dalam penelitian ini adalah:

\section{Data Primer}

Data primer adalah data-data yang di dapat secara langsung dari pemilik dan karyawan perusahaan.

\section{Data sekunder}

Data sekunder adalah data berupa publikasipublikasi yang di dapat dari perusahaan berupa sejarah singkat perusahaan, Struktur organisasi, data jumlah karyawan dan sebagainya.

\section{Analisa Data}

Dalam melakukan penulisan ini, Metode yang digunakan oleh penulis adalah metode deskriptif, yaitu menguraikan data-data yang berhasil diperoleh oleh perusahaan kemudian dikaitkan dengan teori-teoriyang releven dengan pelaporan dan kemudian disimpulkan.

Metode Pengumpulan data

Dalam penelitian, teknik pengumpulan data merupakan faktor penting demi keberhasilan penelitian. Hal ini berkaitan dengan bagaimana cara pengumpulan data, siapa sumbernya, dan apa alat yang digunakan. Jenis sumber data adalah mengenai dari mana data peroleh. Apakah dat diperoleh dari sumber langsung(data primer) atau diperoleh dari sumber tidak langsung (data sekunder).

1. Wawancara/Interview

Wawancara, yaitu metode pengumpulan data yang menghendaki komunikasi langsung antara peneliti dengan pemilik perusahaan(Zuriah,2002)

Wawancara adalah proses memperoleh keterangan untuk tujuan peneltian dengan cara tanya jawab dengan pemilik perusahaan atau karyawan.

2. Observasi

Observasi, yaitu pengamatan dan pencatatan secara sistematis terhadap gejala yang tampak pada objek pada awal penelitian (Zuriah, 2002:83)

Yaitu penulis melakukan pengamatan yang dilakukan yang keperusahann.

\section{HASIL PENELITIAN DAN PEMBAHASAN}

Analisa Volume Penjualan

Salah satu analisa terpenting yang dilakukan oleh perusahaan adalah analisis volume penjulan, Hal ini di maksud untuk mengetahui maju mundurnya perusahaan tersebut dalam memasarkan produk yang dihasilkan, Dengan analisa tersebut dapat terungkap apakah penjualan produk perusahaan mengalami kenaikan atau penurunan.Kaitannya dengan penelitian ini, penulis mencoba mengenalisa perkembangan volume penjualan perusahaan Genteng UD. Berkah jaya selama tahun 2016-2018. Adapun data yang diperoleh merupakan data jumlah produk yang terjual selama tahun 2016-2019 melihat data tersebut dapat terungkap, Apakah volume penjualan meningkat atau menurun. Berikut adalah total volume penjualan perusahaan Genteng UD. Berkah jaya.

Volume Penjualan Genteng Periode Tahub 20162018 


\begin{tabular}{|c|c|c|c|c|}
\hline \multirow[t]{2}{*}{ No } & \multirow[t]{2}{*}{ Jenis Prodak } & \multicolumn{3}{|l|}{ Tahun } \\
\hline & & 2016 & 2017 & 2018 \\
\hline 1 & Mantili & $\begin{array}{l}185.000 \text { keping } \\
\text { Genteng }\end{array}$ & $\begin{array}{l}166.000 \text { Keping } \\
\text { Genteng }\end{array}$ & $\begin{array}{l}185.000 \text { Keping } \\
\text { Genteng }\end{array}$ \\
\hline 2 & \begin{tabular}{|l|l} 
Glombang \\
\end{tabular} & $\begin{array}{l}190.000 \text { Keping } \\
\text { Genteng }\end{array}$ & $\begin{array}{ll}153.000 & \text { Keping } \\
\text { Genteng } & \end{array}$ & $\begin{array}{l}153.000 \text { Keping } \\
\text { Genteng }\end{array}$ \\
\hline 3 & Botol & $\begin{array}{l}180.000 \text { Keping } \\
\text { Genteng }\end{array}$ & $\begin{array}{l}156.000 \text { Keping } \\
\text { Genteng }\end{array}$ & $\begin{array}{l}160.000 \text { Keping } \\
\text { Genteng }\end{array}$ \\
\hline \multicolumn{2}{|c|}{\begin{tabular}{|l|l|} 
Jumlah \\
\end{tabular}} & $\begin{array}{l}555.000 \text { Keping } \\
\text { Genteng }\end{array}$ & $\begin{array}{l}475.000 \text { Keping } \\
\text { Genteng }\end{array}$ & $\begin{array}{l}498.000 \text { Keping } \\
\text { Genteng }\end{array}$ \\
\hline
\end{tabular}

Dari tabel di atas dapat dilihat bahwa volume penjualan pada tahun 2016 sebesar Rp. 555.000,untuk tahun berikutnya 2017 volume penjualan Rp. 475.000, berarti pada tahun 2016 perusahaan mengalami penurunan, dan pada tahun 2018 volume penjualan Rp. 498.000, berati pada tahun 2018 perusahaan mengalami kenaikan disebabkan permintaan Genteng mandili meningkat, Jika dilihat dari tahun ketahun penjualan perusahaan mengalami penurunan faktor yang mempengaruhi penjualan menurun pada perusahaan Genteng UD. Berkah jaya yaitu:

1. Kurangnya Strategi pemasaran atau promusi yang dilakukan oleh perusahaan.

PerusahaanUd. Berkah jaya dalam melakukan pemasaran atau promusi masih menggunakan cara tradisional yaitu masih menggukan tatap muka langsung atau sistem mulut kemulut, Maka dari itu perusahaan UD. Berkah jasa harus mengambil keputusan atau tindakan untuk mngatasi permasalahan tersebut. Salah satu cara yaitu dengan mempromusikan produknya menggunakan media sosial seperti Facebook, Whatsap, Instagram, dan sejenisnya. Selain itu juga harus menggunakan mempromusikan produknya menggunakan brosur dan kerja sama dengan kontraktor, toko bangunan agar perusahaan bisa bersaing dengan perusahaan sejenisnya.

Bauran Pemasaran

Proses pemasaran adalah proses tentang bagaimana perusahaan dapat memasarkan produk atau mempengaruhi konsumen, agar para konsumen bisa membeli produk yang ditawarkan dan akhirnya konsumr menjadi puas sehingga mereka akan selalu membeli produk perusahaan itu, dan perusahaan tidak akan pernah kehingan pangsa pasar atau konsumen sehingga produk itu terus laku dipasaran.

Bagaimana perusahaan itu agar dapat mempengaruhi konsumen merupakan hal yang memerlukan perencanaan dan pengawasan yang matang serta perlu dilakukan tindakan-tindakan yang terdiri dari 4 macam yaitu:

a. Produk (Product)

Produk adalah segala sesuatu baik yang bersifat fisik maupun nonfisik yang dapat ditawarkan kepada konsumen untuk memenuhi kebutuhan atau keinginan, Konsumen memandang produk sebagai ikatan atau bandelen manfaat yang kompleks yang dapat memuaskan keinginan dan kebutuhan konsumen sebaik- baiknya.

Perencanaan sebuah produk juga meliputi aktivitas-aktivitas tertentu yang dilaksanakan dengan produk, seperti halnya mengendentifikasi suatu produk untuk membedakan dengan produk yang lain dengan jalan memberikan merk, serta cirihas dari produk. UD. Berkah jaya sangat memperhatikan kualitas produk yang dihasilkan. Oleh karena ituUD. Berkah jaya berusaha agar produk yang dihasilkan dapat menarik konsumen untuk membeli produk tersebut.

UD. Berkah jaya mempuyai produk jasa genteng dengan berbagai motif jenis-jenis genteng mulai dari genteng mantili, genteng glombang, genteng botol,

\section{Harga (Price)}

Harga merupakan salah satu elemen dari marketing mix yang digunakan perusahaan untuk mencapai sasaran pemasarannya, Penentuan harga jual merupakan hal yang penting dalam kebijakan pemasaran. Hal-hal penting dalam penyusunan kebijakan harga adalah sebagai berikut:

Tujuan penetapan harga yaitu:

1. Meningkatkan volume penjualan

dalam memajukan dan mengembangkan perusahaanya maka dalam volume penjualan diusahakan terus meningkatkan dan dapat bertahan sehingga perusahaan tidak mengalami kemunduran.

2. Mencapai laba maksimal

Untuk mencapai lama maksimal berusaha memenuhi kepuasan konsumen dengan cara memberikan produk yang berkualitas baik sehingga konsumen merasa tidak kecewa dan kembali membeli produk tersebut.

Harga dari produk perusahaan UD. Berkah jaya bisa dibilang lebih tinggi dari pada perusahaan sejenisnya, namun yang membuat produk genteng lebih tinggi adalah kualitas dari produk tersebut, Kualitas dari produk UD.Berkah jaya tidak usah diragukan lagi masalah kualitasnnya. Dalam sistem pemasaran yang dilakukan oleh perusahaan dalam memasarkan genteng, UD. Berkah jaya menjual genteng dengan harga berfariasi tergantung jenisjenis gentengnya.

Dan harga ini terjangkau bagi semua kalangan baik kalangan bawah hingga kalangan atas, Hal ini 
dikarnakan bahan baku yang memang merupakan sumber daya alam dilingkungan sendiri sehingga dapat menekan pada harga produksi dan menjadikan genteng menjadi murah dan terjangkau untuk semua kalangan.

Promosi(Promotion)

Promosi adalah suatu komunikasi dari penjual dan pembeli yang berasal dari informasi yang bertujuan untuk merubah sikap dan tingkah laku pembeli yang sebelimnya tidak mengenal menjadi mengenal yang sebelumnya tidak membeli menjadi membeli.

Cara promosi di perusahaan UD. Berkah jaya ini masih dibilang cukup sederhana, karena masih menggunakan cara bertatap langsung atau system mulut kemulut dan mendatanggi kerumah-rumah konsumen untuk memasarkan genteng. Maka dari itu perusahaan Mita sejahtera jangan sampai menyia-nyiakan kecanggihan teknologi seperti saat saat ini perusahaan harus bisa mempromosikan produknya menggunakan medis sosial,dan yang lainnya.

Tempat(Place)

Salah satu faktor penting dalam menentukan perusahaan adalah lokasi perusahaan tersebut, dimana lokasi perusahaan harus strategi dan dapat dijangkau oleh konsumen, dan masuknya akses transportasi keperusahaan, Tempat bisa diartikan sebagi pemilihan tempat usaha dan pemilihan tempat untuk pelayanan. UD. Berkah jaya berjarak sekitar $25 \mathrm{~km}$ dari kota sampang di kecamatan karang desa tlambah yang terletak didaratan tinggi, perusahaan bisa terjangkau oleh konsumen karna perusahaan tersebut berada dipinggir jalan raya karang penang tempat tersebut sangatlah strategis.

\section{KESIMPULAN DAN SARAN}

Kesimpulan

Dari hasil pembahasab di atas dapat disimpulkan bahwa sebagai berikut:

1. Faktor yang mempengaruhi volume penjualan menurun pada perusahaan UD. Berkah jaya adalah Kurangnya strategi pemasaran yang dilakukan oleh perusahaan.

2. Dalam memasarkan produknya masih menggunakan cara tradisional dengan cara bertatap muka langsung atau sistem mulut kemulut.

3. Perusahaan UD.Berkah jaya menjuala beberapa jenis Genting diantaranya Genting Glombang, Genting botol, Genting pres, dan Genting Mandili.

Saran

1. Strategi promusi perusahaan Genteng UD.
Berkah jaya perlu melakukan promusi melalui media sosial seperti Facebook, Whatsap, Instagram, dan sejenisnya serta perlu bekerja sama dengan para kontraktor dan toko bangunan untuk memasarkan produknya.

\section{DAFTAR PUSTAKA}

Basu Swasta. 2002 Manajemen Pemasara Edisi Kedua. Cetakan kedelapan Jakarta Penerbit liberty

hotler. Philip dan Keler, Kevin lane.2009. Manajemen Pemasaran.(Edisi Ketiga Belas) Jilid 1 Erlangga.

Karnelis. (2017). Pengaruh Bauran Pemasaran terhadap keputusan Konsumen menggunakan Jasa Hotel Kartika Langsa. Jurnal Manajemen dan Keuangan Sekolah Tinggi Ilmu Manajemen Pase, 6(1).

Nurgiyantoro, Singgih.2014. Pengaruh Strategi Pemasaran Promosi melalui Media Sosial Tehadap Keputusan Pembelian Ganskin yang dimediasi Word Of Marketing. Skripsi. Universitas Negeri Yogyakarta.

Kotler, Philip. 1996 Marketing. Jilid I (Edisi Bahasa Indonesia dari Marketing Essentials). Diterjemahkan oleh: Hurujati Purwoto. Jakarta: Penerbit Erlangga. 